\title{
FEATURE Conceptual basis of managing soil carbon: Inspired by nature and driven by science
}

\author{
Rattan Lal
}

$\mathrm{T}$

he anthropogenically induced increase of $146 \%$ in atmospheric concentration of carbon dioxide $\left(\mathrm{CO}_{2}\right)$, from $278 \mathrm{ppm}$ in the preindustrial era (circa 1750) to $405.5 \mathrm{ppm}$ in 2017 , is presently increasing at the rate of $2.24 \mathrm{ppm}$ $\mathrm{y}^{-1}(0.55 \%)$ (WMO 2018). This increase, along with those of methane $\left(\mathrm{CH}_{4}\right.$; from $722 \mathrm{ppb}$ to $1,859 \mathrm{ppb}$ by $257 \%$ and increasing at the rate of $0.38 \%$ or $\left.6.9 \mathrm{ppb} \mathrm{y}^{-1}\right)$ and nitrous oxide $\left(\mathrm{N}_{2} \mathrm{O}\right.$; from $270 \mathrm{ppb}$ to 330 $\mathrm{ppb}$ at the rate of $0.27 \%$ or $\left.0.93 \mathrm{ppb} \mathrm{y}^{-1}\right)$ has already caused $\sim 1^{\circ} \mathrm{C}\left(1.8^{\circ} \mathrm{F}\right)$ increase in global temperature since the Industrial Revolution (IPCC 2018) with dire consequences as exemplified by the increase in frequency of extreme events throughout the world. However, there is still a chance to implement the Paris Climate Agreement proposed at the Paris Climate Conference (COP21) in 2015 and limit the global warming to $1.5^{\circ} \mathrm{C}\left(2.7^{\circ} \mathrm{F}\right)$. To achieve this limit, however, the world must identify noncarbon (C) fuel sources and simultaneously adopt techniques of removing $\mathrm{CO}_{2}$ from the atmosphere or implement negative emission technologies (NET). Carbon sequestration in soil is an important NET option with numerous cobenefits of enhancing agricultural production, improving water resources, and strengthening biodiversity (Lal 2010).

Carbon sequestration in the terrestrial biosphere, with a technical cumulative $\mathrm{C}$ sink capacity of $155 \mathrm{Pg} \mathrm{C}\left(158.6 \times 10^{9} \mathrm{tn}\right.$ C) in vegetation and $178 \mathrm{Pg} \mathrm{C}(182.1 \times$ $10^{9}$ tn C) in soil by 2100 (Lal et al. 2018), is equivalent to drawdown of atmospheric $\mathrm{CO}_{2}$ by $156 \mathrm{ppm}$. Of the total drawdown potential, drawdown through sequestration of soil organic $\mathrm{C}$ (SOC) is $\sim 84 \mathrm{ppm}$ of $\mathrm{CO}_{2}$. However, the large $\mathrm{C}$ sink capacity of the terrestrial biosphere must be accompanied by a complete moratorium on fossil fuel combustion by 2050 , another 32 years from now. To limit the global warming to

Rattan Lal is a distinguished professor of soil science and the director of the Carbon Management and Sequestration Center at The Ohio State University, Columbus, Ohio. $1.5^{\circ} \mathrm{C}\left(2.7^{\circ} \mathrm{F}\right)$, the atmospheric concentration of $\mathrm{CO}_{2}$ at $405.5 \mathrm{ppm}$ in 2017 must not exceed $560 \mathrm{ppm}$ by 2050. Whereas the cumulative emissions from fossil fuel combustion between 1960 and 2017 is estimated at $350 \mathrm{Pg} \mathrm{C}\left(358.1 \times 10^{9}\right.$ tn C), additional emissions until 2050 must not exceed $328 \mathrm{Pg} \mathrm{C}\left(335.6 \times 10^{9}\right.$ tn $\left.\mathrm{C}\right)$ as described below and shown in figure 1 :

$$
\begin{aligned}
& \left(560 \mathrm{ppm} \mathrm{CO} \mathrm{CO}_{2}-405.5 \mathrm{ppm} \mathrm{CO} \mathrm{CO}_{2}\right) \\
& \div\left(\mathrm{Pg} \mathrm{C} / 0.47 \mathrm{ppm} \mathrm{CO} \mathrm{CO}_{2}\right)=328 \mathrm{Pg} \mathrm{C}
\end{aligned}
$$

The present rate of fossil fuel combustion of $9.9 \mathrm{Pg} \mathrm{C}\left(10.1 \times 10^{9}\right.$ tn C) in 2017 (Le Quéré et al. 2018) must decline to 0 by 2050 with the maximum cumulative $\mathrm{C}$ emission of $328 \mathrm{Pg}$ (figure 1). Thus, the objective of this article is to describe the processes and practices of soil $\mathrm{C}$ sequestration to limiting the global warming to $1.5^{\circ} \mathrm{C}\left(2.7^{\circ} \mathrm{F}\right)$.

\section{SOIL CARBON POOL}

The soil C pool consists of two related but different components: the SOC pool and the soil inorganic C (SIC) pool, which strongly impact the global C cycle (GCC). The SOC pool, derived from the decomposition of the remains of plants and animals and the by-products of microbial processes, is estimated at $1,505 \mathrm{Pg}$ $\left(1,539.8 \times 10^{9} \mathrm{tn}\right)$ to $1 \mathrm{~m}(3.28 \mathrm{ft})$ depth (Batjes 1996). In addition, Cryosols (frozen soils or the permafrost) may contain as much as $1,672 \mathrm{Pg} \mathrm{C}\left(1,710.6 \times 10^{9}\right.$ tn C) (Jungkunst et al. 2012). The SIC pool consists of carbonates derived from the weathering of parent rocks (lithogenic or primary carbonates) and those formed from the dissolution of $\mathrm{CO}_{2}$ in soil air to form a weak carbonic acid and its reaction with the bases brought in from outside the system (pedogenic or secondary carbonates). The magnitude of the SIC pool is estimated at $940 \mathrm{Pg} \mathrm{C}\left(961.7 \times 10^{9}\right.$ tn C) to $1 \mathrm{~m}$ (3.28 ft) depth (Monger et al. 2015). The SIC pool also consists of bicarbonates in groundwater estimated at $1,404 \mathrm{Pg} \mathrm{C}$ $\left(1,436.4 \times 10^{9}\right.$ tn $\left.\mathrm{C}\right)$; there is a strong flux of $\mathrm{CO}_{2}$ into the groundwater (Kessler and
Harvey 2001). Altogether, the SIC pool is about $2,344 \mathrm{Pg} \mathrm{C}\left(2,398.1 \times 10^{9}\right.$ tn C) to $1 \mathrm{~m}$ (3.28 ft) depth (Monger et al. 2015). Recalibration of the nonflat earth for terrain and topsoil may increase the estimates of soil C stock to $8,580 \mathrm{Pg} \mathrm{C}(8,778.2 \times$ $10^{9}$ tn C) (Blakemore 2018). With such a large $\mathrm{C}$ pool, in comparison with that of the atmosphere $\left(820 \mathrm{Pg}\left[838.9 \times 10^{9} \mathrm{tn}\right]\right)$ and the biotic pool $\left(620 \mathrm{Pg}\left[634.3 \times 10^{9}\right.\right.$ tn]), a small emission from the soil $\mathrm{C}$ pool can easily overwhelm the atmospheric pool and aggravate the process of global warming. On the contrary, even a small increase in the soil $\mathrm{C}$ pool through storage of biomass $\mathrm{C}$ can have a strong drawdown impact on atmospheric concentration of $\mathrm{CO}_{2}$. Thus, thoroughly understanding and judiciously managing the largest terrestrial C pool (Scharlemann et al. 2014) is of a critical importance to limiting global warming to $1.5^{\circ} \mathrm{C}\left(2.7^{\circ} \mathrm{F}\right)$ and also meeting other demands of the growing and increasingly affluent world population.

Historic land use and the widespread adoption of extractive farming practices, coupled with the severe problem of erosion and other degradative processes, have depleted the SOC pool of agro-ecosystems by as much as $135 \mathrm{Pg} \mathrm{C}$ $\left(138.2 \times 10^{9}\right.$ tn C) $($ Lal 2018a). On the contrary, restoration of degraded soils through conversion to a restorative land use and adoption of recommended management practices can create a positive soil C budget. Through a widespread adoption of NET, therefore, world soils are a viable option for adaptation and mitigation of anthropogenic climate change. The schematic in figure 2 shows that $80 \mathrm{Pg} \mathrm{C}\left(81.8 \times 10^{9}\right.$ tn $\left.\mathrm{C}\right)$ was emitted between 1960 and 2017 from land use change (Le Quéré et al. 2018). However, adoption of the restorative land use and recommended management practices can potentially create a drawdown of about $333 \mathrm{Pg}$ C $(340.7$ $\times 10^{9}$ tn C) between 2020 and 2100 or reduction in atmospheric $\mathrm{CO}_{2}$ by $\sim 156$ $\mathrm{ppm}$ through sequestration of $\mathrm{C}$ in the terrestrial biosphere (Lal et al. 2018). 


\section{Figure 1}

The past emission and the designed reduction in the future emission. Past emissions are drawn from Le Quéré et al. (2018).

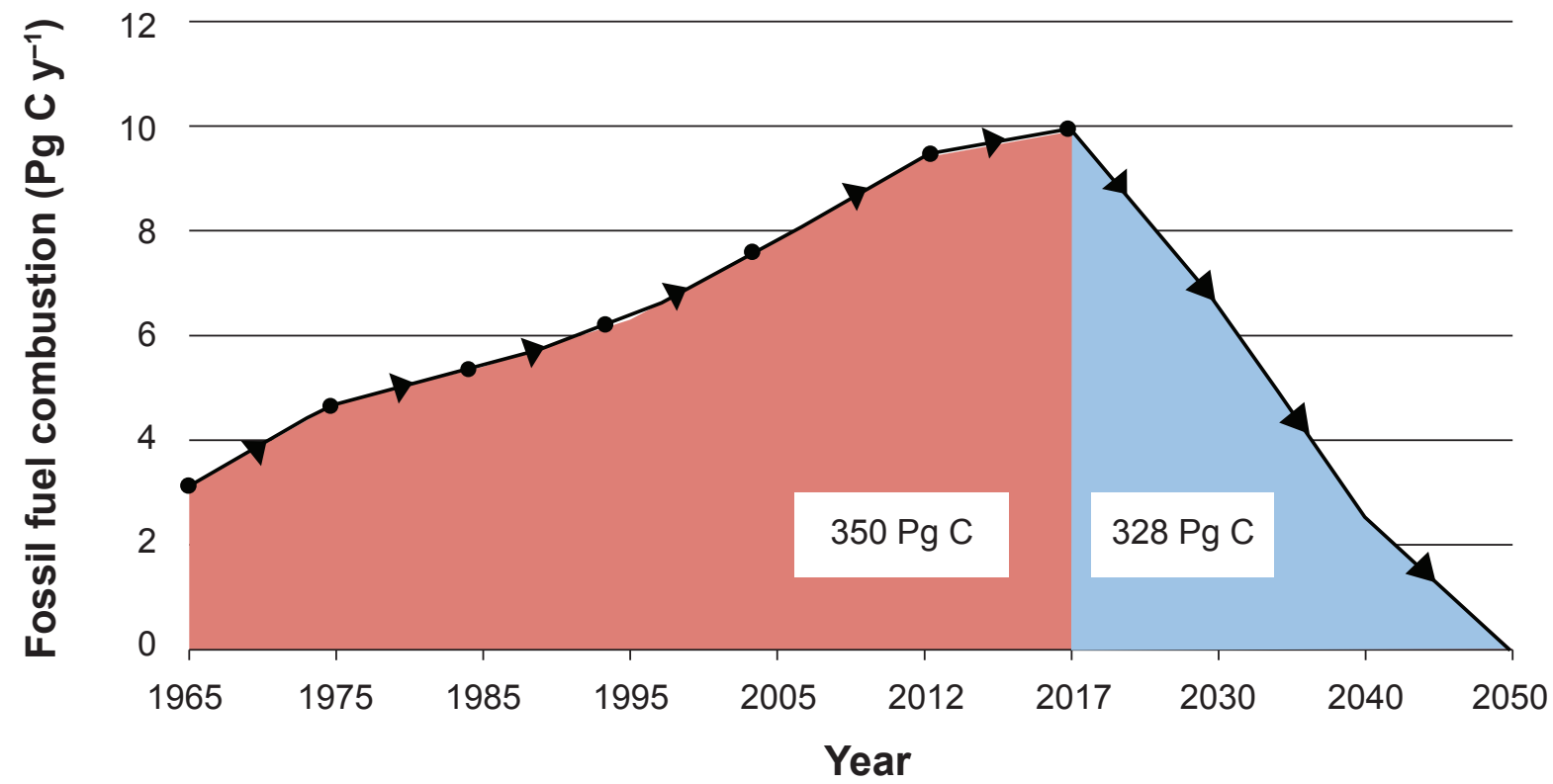

\section{CONCEPTUAL BASIS OF MANAGING} THE SOIL CARBON POOL

The NET of $\mathrm{C}$ sequestration in the terrestrial biosphere is a natural process. All life on the planet Earth depends on the process of biosequestration of atmospheric $\mathrm{CO}_{2}$. Only $0.05 \%$ of the $3,800 \mathrm{ZJ}$ $\left(10^{21} \mathrm{~J} ; 3.6 \times 10^{21} \mathrm{BTU}\right)$ of solar energy is photosynthesized into $123 \mathrm{Pg} \mathrm{C} \mathrm{y}^{-1}$ $\left(1,258 \times 10^{9}\right.$ tn $\left.\mathrm{C} \mathrm{yr}^{-1}\right)$ as gross primary productivity. Of this, $60 \mathrm{Pg} \mathrm{C}\left(61.4 \times 10^{9}\right.$ tn $\mathrm{C}$ ) is respired back and the net primary productivity is $63 \mathrm{Pg} \mathrm{C} \mathrm{y}^{-1}(64.5$ $\times 10^{9}$ tn $\left.\mathrm{C} \mathrm{yr}^{-1}\right)$. With losses by erosion, fire, etc., the net ecosystem productivity is merely $3 \mathrm{Pg} \mathrm{C} \mathrm{y}^{-1}\left(3.07 \times 10^{9}\right.$ tn $\mathrm{C}$ $\mathrm{yr}^{-1}$ ) (Jansson et al. 2010). Anthropogenic emissions of $11.3 \mathrm{Pg} \mathrm{C}\left(11.6 \times 10^{9}\right.$ tn C) in 2017, comprising of $9.9 \mathrm{Pg} \mathrm{C}(10.13$ $\times 10^{9}$ tn C) from fossil fuel combustion and $1.4 \mathrm{Pg}\left(1.43 \times 10^{9} \mathrm{tn}\right)$ from land use change (Le Quéré et al. 2018), can be entirely offset through a judicious management of the terrestrial biosphere to increase net ecosystem productivity to $\sim 10 \%$ of the annual GDP. Dyson (2008) rightfully stated that "if we control what plants do with carbon, the fate of $\mathrm{CO}_{2}$ in the atmosphere is in our hands."

The book The Grapes of Wrath depicted the ramifications of the Dust Bowl of the

\section{Figure 2}

Carbon sequestration in the terrestrial biosphere (data of emission through land use change from Le Quéré et al. [2018], and that of sequestration from Lal et al. [2018]).

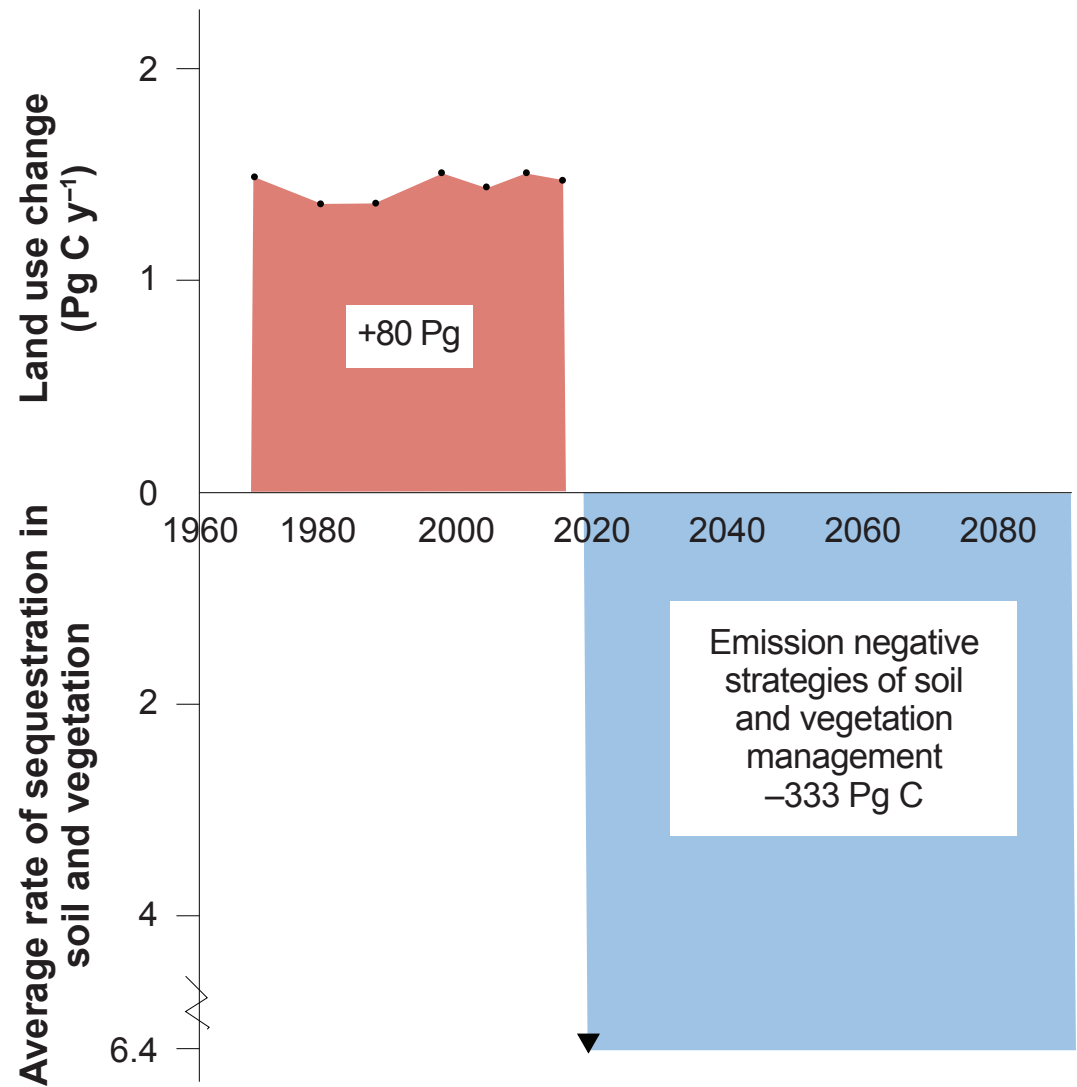


1930s (Steinbeck 1939), and subsequent books on the adverse impacts of plowing (Faulkner 1942) and those of pesticides (Carson 1962) provided the conceptual basis of both the urgency and necessity of sustainable management of soil and other natural resources. These concepts were strongly supported by the warnings regarding degradation of soil resources by accelerated erosion and other processes (Whyte and Jacks 1944; Wood 1950; Lowdermilk 1953; Buck 1931; Commoner 1971). The risks of drastic anthropogenic disturbance of the GCC have been highlighted by Roger Revelle since the 1950s (Revelle and Suess 1957; Revelle et al. 1965; Revelle and Munk 1977; Revelle 1982). Revelle and Suess (1957) observed that increase in atmospheric concentration of $\mathrm{CO}_{2}$ may cause global warming through the Greenhouse Effect, and that the $\mathrm{CO}_{2}$ concentration should be monitored. The latter led to the start of the Keeling Curve (Keeling et al. 1989). Historic evolution of the scientific movement regarding the close interaction between the terrestrial biosphere and the GCC, and the importance of sustainable management of soil resources and restoration of the environment is outlined in figure 3 .

\section{MANAGING SOIL ORGANIC CARBON SEQUESTRATION}

Since the onset of the movement on SOC sequestration early 1990s (figure $3)$, considerable progress has been made in scientific developments (Blankinship et al. 2018). The concept of SOC persistence as an ecosystem property (Schmidt et al. 2011)—based on a balance between decomposition by microbes on the one hand and protection by physical and chemical processes on the other-has been refined (Lehmann and Kleber 2015) in conjunction with the impact of climate (temperature and moisture regimes) on SOC turnover (Lawrence et al. 2015). The importance of physical access to decompositional processes rather than of molecular structure (Dungait et al. 2012; Heckman et al. 2018) along with identification of other protection mechanisms (Six et al. 2002) and the C saturation concept (Castellano et al. 2015) have improved the understanding of the factors governing the mean residence time (MRT) of SOC in soil (Schwendenmann and Pendall 2008). Progress is also being made in measurements and monitoring (Wielopolski et al. 2011), and in understanding the relative importance of sequestration in surface vs. subsoil (Matteodo et al. 2018; Hobley et al.
2016; Moni et al. 2010; Wordell-Dietrich et al. 2017), rhizospheric processes (Vidal et al. 2018), microaggregates and SOC turnover (Totsche et al. 2018; Pavithra et al. 2018), nutrient supply (Liang et al. 2019), impact of land use change (Chenu et al. 2018), and of SOC fractions (Poeplau et al. 2018). Despite the progress in science (Lal 2018a) and technologies (Batjes 2018), the scientific knowledge to enhance SOC and SIC pools has not been effectively translated into an action plan at local, regional, national, or global scales.

\section{MANAGING SOIL INORGANIC CARBON}

Sequestration of SIC, as secondary carbonates and through leaching of bicarbonates, is also an important but much less researched theme (Lal 2009; Zamanian et al. 2016). Yet, SIC is a significant component of the GCC and is a major C constituent in soils of dry climates, which cover about $41 \%$ of Earth's land surface (Gao et al. 2017). Furthermore, the MRT of carbonates may be as long as 85,000 years compared with 35 years for SOC, 10 years for vegetation, and 5 years for the atmosphere (Schlesinger 1985, 2002; Monger et al. 2015). Restoration of degraded and desertified lands in dry areas lead to sequestration of SIC as pedogenic

\section{Figure 3}

Historical evolution of movements regarding awareness about environmental issues and the importance of soil management.

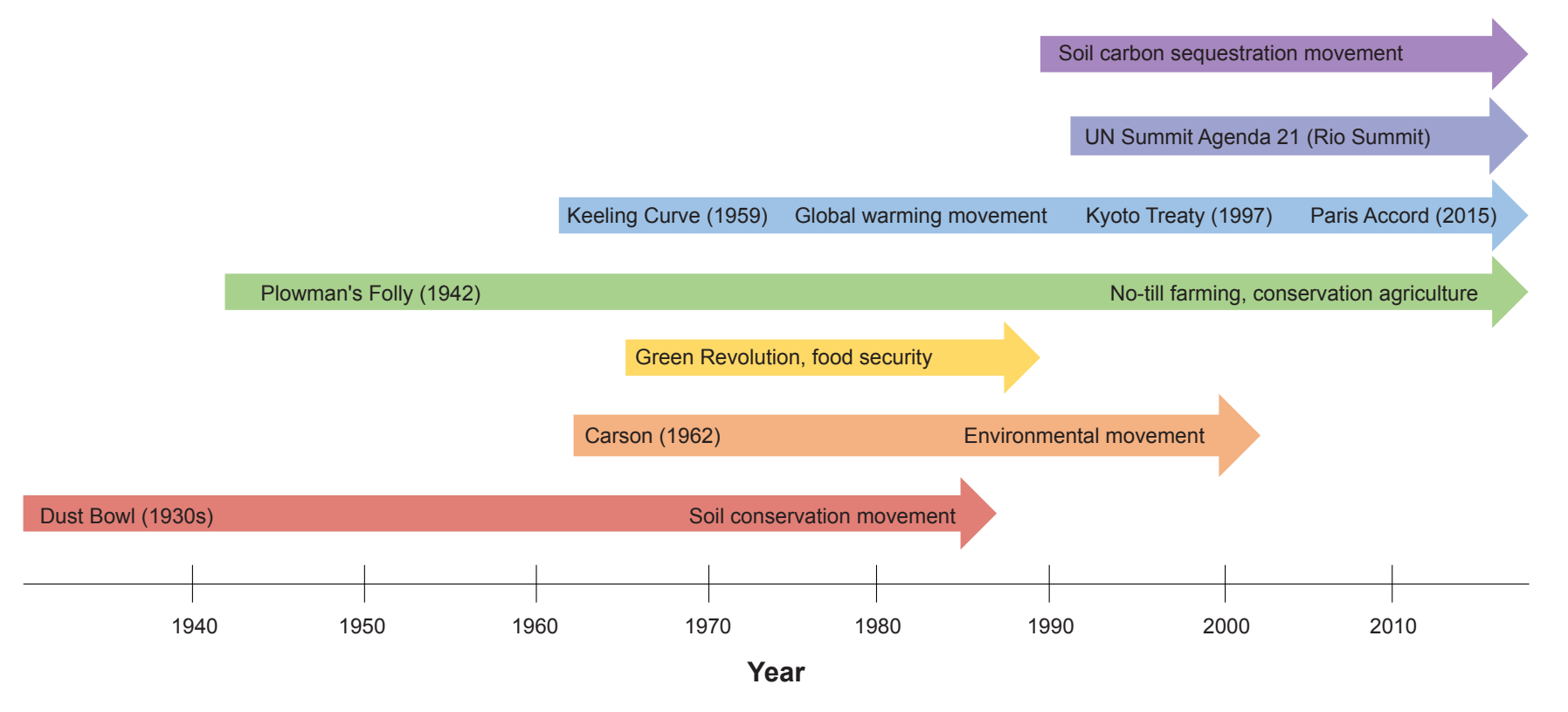


carbonates. In northwestern China, Gao et al. (2017) observed that the antecedent SIC stock of $32.4 \mathrm{Mg} \mathrm{ha}^{-1}$ (14.45 $\mathrm{tn} \mathrm{ac}^{-1}$ ) to $1 \mathrm{~m}$ (3.28 ft) depth increased to 42.5 , 49.2, and 68.3 $\mathrm{Mg} \mathrm{ha}^{-1}(18.96,21.95$, and $\left.30.47 \mathrm{tn} \mathrm{ac}^{-1}\right)$ with afforestation of white poplar (Populus alba L.) after 8, 20, and 30 years of establishment probably because of the formation of pedogenic carbonates. Similar observations on SIC under poplar have been reported ( $\mathrm{Su}$ et al. 2010). Further, formation of secondary carbonates is also closely related to the SOC concentration because of the increase in $\mathrm{CO}_{2}$ concentration and precipitation of carbonates with cations brought in from outside the system (Monger et al. 2015; Wang et al. 2015; Guo et al. 2016; Zhang et al. 2010). Soil inorganic C is relatively stable with a long MRT.

In addition to the dynamics of SOC and SIC in the surface layer, it is also pertinent to study the changes in both the surface and subsoil with regard to stocks of SOC following afforestation of degraded and desertified lands. Factors affecting SOC and SIC dynamics differ among surface and subsoil layers. Soil moisture and temperature regimes, as moderated by the climate, affect SOC through changes in vegetative growth and the effect on input of biomass-C (Davidson and Janssens 2006). In contrast, land use, afforestation, and drainage affect $\mathrm{C}$ dynamics in the subsoil (Tan et al. 2014). Thus, climatic variables and land use can have strong interactive effects on SOC and SIC dynamics in both surface and subsoil layers. Based on a study conducted on a precipitation gradient across the Loess Plateau of China, Han et al. (2018) reported that sequestration of $1 \mathrm{~kg} \mathrm{SOC} \mathrm{m^{-2 }}(0.2048 \mathrm{lb}$ SOC $\left.\mathrm{ft}^{-2}\right)$ in the 0 to $0.4 \mathrm{~m}(1.31 \mathrm{ft})$ depth by afforestation reduced the SIC by $0.73 \mathrm{~kg}$ $\mathrm{m}^{-2}\left(0.15 \mathrm{lb} \mathrm{ft}^{-2}\right)$ but increased it by 1.26 $\mathrm{kg} \mathrm{SIC} \mathrm{m} \mathrm{m}^{-2}\left(0.26 \mathrm{lb} \mathrm{SIC} \mathrm{ft}^{-2}\right)$ in the 0.4 to $3.0 \mathrm{~m} \mathrm{(1.31} \mathrm{to} 9.8 \mathrm{ft})$ layer. Han and colleagues hypothesized that the depth distribution and relative sequestration of SOC vs. SIC depend on climate, land use, and the predominant species. Han and colleagues also observed that the total SOC and SIC stocks in 1.0 to $3.0 \mathrm{~m}(3.28$ to $9.84 \mathrm{ft})$ depth were more than $50 \%$ of the stocks in the 0 to $1.0 \mathrm{~m}$ (0 to 3.28 ft) layer. Additional research needed on SIC dynamics in soils of arid and semiarid regions can be preferably done by the use of isotope technology such as carbon-13 $\left({ }^{13} \mathrm{C}\right)$, calcium-45 $\left({ }^{45} \mathrm{Ca}\right)$ and oxygen-18 $\left({ }^{18} \mathrm{O}\right)$ (Bai et al. 2017).

Leaching of bicarbonates into the groundwater is another important mechanism of SIC sequestration. With large SIC stock of $1,404 \mathrm{Pg} \mathrm{C}\left(1,436.4 \times 10^{9}\right.$ tn $\left.\mathrm{C}\right)$ as bicarbonates, changes of SIC concentration in the groundwater of as much as 5 mmol L ${ }^{-1}$ can strongly impact the GCC (Zhu and Schwartz 2011; Monger et al. 2015). Leaching of bicarbonates in the irrigated soils $\left(350\right.$ Mha $\left[864.5 \times 10^{6} \mathrm{ac}\right]$ globally) is an important sink that needs to be carefully evaluated. Contrary to the process of the formation of secondary carbonates, sequestration of SIC in the groundwater does not depend on the availability of $\mathrm{Ca}^{+2}$ and other cations.

TRANSLATING SCIENCE INTO ACTION

There are two necessary prerequisites to using scientific knowledge to enhance the soil C pool. First is the identification of sitespecific technologies of land use and soil/ crop/animal management. The second is the policy interventions toward adoption of these technologies. Because of the large variation in global agroecosystems (i.e., soil, climate, terrain, crops, farming system, and the human dimensions), there is no single technology that can be universally applicable. With site-specific adaptation, examples of some technologies that can create a positive soil/ecosystem C budget include a system-based conservation agriculture (Lal 2015), agroforestry (Cardinael et al. 2018), organic and inorganic fertilization (Körschens et al. 2013; Wang et al. 2014), controlled grazing (Dlamini et al. 2016), indigenous cyanobacterial application on structurally unstable soils (Nisha et al. 2007), increased activity and species diversity of all biota (Schmitz et al. 2018), legume-based rotations (Sainju and Lenssen 2011), and cover cropping (Olson et al. 2014). The Climate Accord proposed at COP21 in Paris in 2015 also initiated the "4 perThousand" program of sequestering SOC in world soils at the annual rate of $0.4 \%$ per year to $40 \mathrm{~cm}$ depth (Chambers et al. 2016). A similar initiative was pro- posed at COP22 in 2016 in Marrakesh (Lal 2018b). These initiatives are examples of attempts to translate knowledge of soil science into policy. Implementation of these and other initiatives at local, national, and regional levels would be a step in the right direction.

\section{THE POWER OF SOIL CARBON SEQUESTRATION AS EMISSION NEGATIVE}

The soil C pool, the largest reservoir of the terrestrial biosphere, has a vast potential to impact the GCC and limit global warming. Despite the suggestions by some to be cautious about the potential of soil to mitigate global warming (Amundson and Biardeau 2018; Schlesinger and Amundson 2018; Cheng et al. 2012), the strong impact on the GCC and numerous cobenefits of SOC sequestration necessitate an urgent action to translate the scientific knowledge into action. The latter would encompass adoption of proven management technologies of soil (i.e., conservation agriculture, biochar, agroforestry, integrating crops with trees and livestock, and recycling biomass), water $\mathrm{C}$ harvesting and recycling (through drip subirrigation and other microirrigation systems), livestock (controlled grazing and manure management) and plants (deep root systems and recalcitrant compounds) at local, regional, national, and global scales. A widespread adoption of proven technologies would also involve incentivization of farmers and land managers through payments for provisioning of ecosystem services strengthened by SOC sequestration on the basis of the societal value of soil C (Lal 2014). Soil scientists, in close cooperation with agronomists, foresters, geologists, and extension specialists, must seize the moment by working with policy makers to manage soil as a NET. The soilcentric approach, inspired by nature and driven by science, is also critical to advancing the Sustainable Development Goals of the United Nations or the Agenda 2030.

\section{REFERENCES}

Amundson, R., and L. Biardeau. 2018. Opinion: Soil carbon sequestration is an elusive climate mitigation tool. Proceedings of the National Academy 
of Sciences of the United States of America 115:11652-11656.

Bai, S.G., Y. Jiao, W.J.Yang, P. Gu, J.Yang, and L.J. Liu. 2017. Review of progress in soil inorganic carbon research. IOP Conference Series: Earth and Environmental Sciences 100(2017).

Batjes, N.H. 1996. Total carbon and nitrogen in soils of the world. European Journal of Soil Science 47:151-163.

Batjes, N.H. 2018. Technologically achievable soil organic carbon sequestration in world croplands and grasslands. Land Degradation and Development 30:25-32.

Blakemore, R.J. 2018. Non-flat earth recalibrated for terrain and topsoil. Soil Systems 2(4):64.

Blankinship, J.C., A.A. Berhe, S.E. Crow, J.L. Druhan, K.A. Heckman, M. Keiluweit, C.R. Lawrence, et al. 2018. Improving understanding of soil organic matter dynamics by triangulating theories, measurements and models. Biogeochemistry 140(1):1-13.

Buck, P. 1931. The Good Earth. New York: John Day.

Cardinael, R., K. Hoeffner, C. Chenu, T. Chevallier, C. Beral, A. Dewisme, and D. Cluzeau. 2018. Spatial variation of earthworm communities and soil organic carbon in temperate agroforestry. Biology and Fertility of Soils 55:171-183.

Carson, R. 1962. Silent Spring. New York: Houghton Mifflin.

Castellano, M.J., K.E. Mueller, D.C. Olk, J.E. Sawyer, and J. Six. 2015. Integrating plant litter quality, soil organic matter stabilization, and the carbon saturation concept. Global Change Biology 21(9):3200-3209.

Chambers, A., R. Lal, and K. Paustian. 2016. Soil carbon sequestration potential of US croplands and grasslands: Implementing the 4 per Thousand Initiative. Journal of Soil and Water Conservation 71(3):68A-76A, doi:10.2489/jswc.71.3.68A.

Cheng, L., F.L. Booker, C. Tu, K.O. Burkey, L. Zhou, D. Shew, T.W. Rufty, and S. Hu. 2012. Arbuscular mycorrhized fungi increase organic carbon decomposition under elevated $\mathrm{CO}_{2}$. Science 337:1084-1087.

Chenu, C., D.A. Angers, P. Barré, D. Derrien, D. Arrouays, and J. Balesdent. 2018. Increasing organic stocks in agricultural soils: Knowledge gaps and potential innovations. Soil and Tillage Research 1-11.

Commoner, B. 1971. The Closing Circle: Nature, Man and Technology. New York: Alfred A. Knopf Inc.

Davidson, E.A., and I.A. Janssens. 2006. Temperature sensitivity of soil carbon decomposition and feedbacks to climate change. Nature 440:165-173.

Dlamini, P., P. Chivenge, and V. Chaplot. 2016. Overgrazing decreases soil organic carbon stocks the most under dry climate and low soil $\mathrm{pH}$ : A meta-analysis shows. Agriculture, Ecosystems and Environment 221:258-269.

Dungait, J., D.W. Hopkins, A.S. Gregory, and A.P. Whitmore. 2012. Soil organic matter turnover is governed by accessibility not recalcitrance. Global Change Biology 18:1781-1796.

Dyson, F. 2008. The question of global warming. New York Reviews of Books, June 12, 2008. https:// www.nybooks.com/articles/2008/06/12/ the-question-of-global-warming/.

Faulkner, E. 1942. Plowman's Folly. London: Michael Joseph, Ltd.

Gao,Y., J.Tian,Y. Pang, and J. Liu. 2017. Soil inorganic carbon sequestration following afforestation is probably induced by pedogenic carbonate formation in northwest China. Frontiers in Plant Science 8:1282

Guo, Y., X.J. Wang, X.Q. Li, J. Wang, M. Xu, and D. Li. 2016. Dynamics of soil organic and inorganic carbon in the cropland of upper Yellow River Delta, China. Scientific Reports 6:36105.

Ha, X., Y. Yang, C. Zhang, M. Shao, and L. Huang. 2017. A state-space analysis of soil organic carbon in China's Loess Plateau. Land Degradation and Development 28:983-993.

Heckman, K., H. Throckmorton, W.R. Horwath, C.W. Swanston, and C. Rasmussen. 2018. Variation in the molecular structure and radiocarbon abundance of mineral-associated organic matter across a lithosequence of forest soils. Soil Systems 2(2):1-12.

Hobley, E., J. Baldock, Q. Hua, and B. Wilson. 2016. Land-use contrasts reveal instability of subsoil organic carbon. Global Change Biology 23(2):955-965.

IPCC (Intergovernmental Panel on Climate Change). 2018. Global warming of $1.5^{\circ} \mathrm{C}$. Summary for Policy Makers. Switzerland: World Meteorological Organization, United Nations Environment Program, and Intergovernmental Panel on Climate Change.

Jansson, C., S.D. Wullschleger, U.C. Kalluri, and G.A. Tuskan. 2010. Phytosequestration: Carbon biosequestration by plants and prospects of genetic engineering. BioScience 60:685-696.

Jungkunst, H., J.P. Krüger, F. Heitkamp, S. Erasmi, S. Glatzel, S. Fiedder, and R. Lal. 2012. Accounting more precisely for peat and other soil carbon resources. In Recarbonization of the Biosphere: Ecosystems and the Global Carbon Cycle, eds. R. Lal, K. Lorenz, R.F. Huttl, B.U. Schneider, and J. Von Braun, 127-157. Berlin: Springer.

Keeling, C.D., R.B. Bacastow, A.F. Carter, S.C. Piper, T.P. Wharf, M. Heimann, W.G. Cook, and H. Roeloffzen. 1989. A three-dimensional model of atmospheric $\mathrm{CO}_{2}$ transport based on observed winds. In Analysis of Observational Data, ed. D.H. Peterson. Aspects of Climate Variability in the Pacific and Western America Geophysical Monograph 55:165-235.

Kessler, T.J., and C.F. Harvey. 2001. The global flux of carbon dioxide into groundwater. Geophysical Research Letters 28:279-282.

Körschens, M., E.Albert, M.Armbruster, D. Barkusky, M. Baumecker, L. Behle-Schalk, R. Bischoff, et al. 2013. Effect of mineral and organic fertilization on crop yield, nitrogen uptake, carbon and nitrogen balances, as well as soil organic carbon content and dynamics: Results from 20 European long-term field experiments of the twenty-first century. Archives of Agronomy and Soil Science 59(8):1017-1040.

Lal, R. 2009. Sequestration of carbon in soils of arid ecosystems. Land Degradation and Development 20(4):441-454.

Lal, R. 2010. Managing soils and ecosystems for mitigating anthropogenic carbon emissions and advancing global food security. BioScience 60(9):708-721.

Lal, R. 2014. Societal value of soil carbon. Journal of Soil and Water Conservation 69(6):186A-192A, doi:10.2489/jswc.69.6.186A.

Lal, R. 2015. A system approach to conservation agriculture. Journal of Soil and Water Conservation 70(4):82A-88A, doi:10.2489/jswc.70.4.82A.

Lal, R. 2018a. Digging deeper: A holistic perspective of factors affecting SOC sequestration. Global Change Biology 24(8), doi:10.1111/gcb.14054.

Lal, R. 2018b. Promoting " 4 per thousand" and "adapting African agriculture" by south-south cooperation: Conservation agriculture and sustainable intensification. Soil and Tillage 188:35-40, doi:10.1016/j.still.2018.02.001.

Lal, R., P. Smith, H.F. Jungkunst, W.J. Mitsch, J. Lehmann, P.K.R. Nair, A.B. McBratney, et al. 2018. The carbon sequestration potential of terrestrial ecosystems. Journal of Soil and Water Conservation 73(6):145A-152A, doi:10.2489/ jswc.73.6.145A.

Lawrence, C.R., J.W. Harden, X. Xu, M.S. Schulz, and S.E. Trumbore. 2015. Long-term controls on soil organic carbon with depth and time: A case study from the Cowlitz River Chronosequence, WA USA. Geoderma 247:73-87.

Le Quéré, C., R.M. Andrew, P. Friedlingstein, S. Sitch, J. Hauck, J. Pongratz, P.A. Pickers, et al. 2018. Global carbon budget 2018. Earth System Science Data 10:2141-2194.

Lehmann, J., and M. Kleber. 2015. The contentious nature of soil organic matter. Nature 528:60-68. 
Liang, Z., J.E. Olesen, J.L. Jensen, and L. Elsgaard. 2019. Nutrient availability affects carbon turnover and microbial physiology differently in topsoil and subsoil under a temperate grassland. Geoderma 336:22-30.

Lowdermilk,W.C. 1953. Conquest of the Land through Seven Thousand Years. Washington, DC: USDA.

Matteodo, M., S. Grand, D. Sebag, M.C. Rowley, P. Vittoz, and E.P. Verrecchia. 2018. Decoupling of topsoil and subsoil controls on organic matter dynamics in the Swiss Alps. Geoderma 330:41-51.

Monger, H.C., R.A. Kraimer, S.E Khresat, D.R. Cole, X. Wang, and J. Wang. 2015. Sequestration of inorganic carbon in soil and groundwater. Geology 43(5):375-378.

Moni, C., C. Rumpel, I. Virto, A. Chabbi, and C. Chenu. 2010. Relative importance of sorption versus aggregation for organic matter storage in subsoil horizons of two contrasting soils. European Journal of Soil Science 61(6):958-969.

Nisha, R., A. Kaushik, and C.P. Kaushik. 2007. Effect of indigenous cyanobacterial application on structural stability and productivity of an organically poor semi-arid soil. Geoderma 138:49-56.

Olson, K., S.A. Ebelhar, and J.M. Lang. 2014. Longterm effects of cover crops on crop yields, soil organic carbon stocks and sequestration. Open Journal of Soil Science 4:284-292.

Pavithra, S., P. Arachchige, G.M. Hettiarachchi, C.W. Rice, J.J. Dynes, L. Maurmann, J. Wang, et al. 2018. Sub-micron level investigation reveals the inaccessibility of stabilized carbon in soil microaggregates. Scientific Reports 8(16810):1-13.

Poeplau, C., A. Don, J. Six, M. Kaiser, D. Benbi, C. Chenu, M. Cotrufo, et al. 2018. Isolating organic carbon fractions with varying turnover rates in temperature agricultural soils-A comprehensive method comparison. Soil Biology and Biochemistry 125:10-26.

Revelle, R. 1982. Carbon dioxide and world climate. Scientific American 247(2):35-43

Revelle, R.,W. Broecker, H. Craig, C.D. Keeling, and J. Smagorinsky. 1965. Atmospheric carbon dioxide. In Restoring the Quality of Our Environment: Report of the Environment Pollution Panel, 111-113. Washington, DC: President's Science Advisory Committee, The White House.

Revelle, R., and W. Munk. 1977. The carbon cycle and the biosphere. In Energy and Climate. National Academy of Sciences 140-178.

Revelle, R., and H. Suess. 1957. Carbon dioxide exchange between atmosphere and ocean and questions of an increase of atmospheric $\mathrm{CO}_{2}$ during the past decades. Tellus 9:18-27.

Sainju, U.M., and A.W. Lenssen. 2011. Dryland soil carbon dynamics under alfalfa and durum-forage cropping sequences. Soil and Tillage Research 113:30-37.

Scharlemann, J.P., R. Hiederer, E. Tanner, and V. Kapos. 2014. Global soil carbon: Understanding and managing the largest terrestrial carbon pool. Carbon Management 5:81-91.

Schlesinger, W.H. 1985. The formation of caliche in soils of the Mojave Desert, California. Geochimica et Cosmochimica Acta 49:57-66.

Schlesinger, W.H. 2002. Inorganic carbon and the global cycle. In Encyclopedia of Soil Science, 672. New York: Academic Press.

Schlesinger, W.H., and R. Amundson. 2019. Managing for soil carbon sequestration: Let's get realistic. Global Change Biology 25(2):386-389.

Schmidt, M.W.I., M.S. Torn, S. Abiven, T. Dittmar, G. Guggenberger, I.A. Janssens, M. Kleber, et al. 2011. Persistence of soil organic matter as an ecosystem property. Nature 478:49-56.

Schmitz, O.J., C.C. Wilmers, S.J. Leroux, C.E. Doughty, T.B. Atwood, M. Galetti, A.B. Davies, and S.J. Goetz. 2018. Animals and the zoochemistry of the carbon cycle. Science 362:1127, doi:10.1126/science.aar3213.

Schwendenmann, L., and E. Pendall. 2008. Response of soil organic matter dynamics to conversion from tropical forest to grassland as determined by long-term incubation. Biology and Fertility of Soils 44:1053-1062.

Six, J., R.T. Conant, E.A. Paul, and K. Paustian. 2002. Stabilization mechanisms of soil organic matter: Implications for C-saturation of soils. Plant and Soil 241(2):155-176.

Steinbeck, J. 1939. Grapes of Wrath. New York: Viking Press.

Su, Y.Z., X.F. Wang, R.Yang, and J. Lee. 2010. Effects of sandy desertified land rehabilitation on soil carbon sequestration and aggregation in an arid region in China. Journal of Environmental Management 91:2109-2116.

Tan, W.F., R. Zhang, H. Cao, C.Q. Huang, Q.K.Yang, M.K. Wang, and L.K. Koopal. 2014. Soil inorganic carbon stock under different soil types and land uses on the Loess Plateau region of China. Catena 121:22-30.

Totsche, K.U., W. Amelung, M.H. Gerzabek, G. Guggenberger, E. Klumpp, C. Knief, et al. 2018. Microaggregates in soils. Journal of Plant Nutrition and Soil Science 181:104-136.

Vidal, A., J. Hirte, S. Franz Bender, J. Mayer, A. Gattinger, C. Höschen, S. Schädler, et al. 2018. Linking 3D soil structure and plant-microbe-soil carbon transfer in the rhizosphere. Frontiers in Environmental Science 6(9):1-14.

Wang, J.P., X.J. Wang, J. Zhang, and C.Y. Zhao. 2015. Soil organic and inorganic carbon and stable carbon isotopes in the Yanqi Basin of northwestern China. European Journal of Soil Science 66:95-103.

Wang, X.J., M.G. Xu, J.P. Wang, W.J. Zhang, X.Y. Yang, S.M. Huang, and H. Liu. 2014. Fertilization enhancing carbon sequestration as carbonate in arid cropland: Assessments of long-term experiments in northern China. Plant and Soil 380:89-100.

Whyte, G.V., and R.O. Jacks. 1944. The Rape of the Earth. London: Faber and Faber.

Wielopolski, L., A. Chatterjee, S. Mitra, and R. Lal. 2011. In-situ determination of soil carbon pool by inelasatic neutron scattering. Geoderma 160:394399, doi:1016/j/Geoderma.2010.10.009.

Wood, A. 1950. The Groundnut Affair. London: Bodley Head.

Wordell-Dietrich, P., A. Don, and M. Helfrich. 2017. Controlling factors for the stability of subsoil carbon in a Dystric Cambisol. Geoderma 304:40-48. WMO (World Meteorological Organization). 2018. The state of greenhouse gases in the atmosphere based on global observations through 2017. Greenhouse Gas Bulletin 8 .

Zamanian, K., K. Pustovoytov, andY. Kuzyakov. 2016. Pedogenic carbonates: Forms and formation processes. Earth-Science Reviews 157:1-17.

Zhang, N., H.E. Xing-Dong, Y.B. Gao, Y.H. Li, H.T. Wang, D. Ma, R. Zhang, and S. Yang. 2010. Pedogenic carbonate and soil dehydrogenase activity in response to soil organic matter in Artemisia ordosica community. Pedosphere 20(2):229-235.

Zhu, C., and F.W. Schwartz. 2011. Hydrogeochemical processes and controls on water quality and water management. Elements 7:169-174. 